\title{
Challenges and Management of Restaurant Waste in Surabaya
}

\author{
Eny Sulistyowati ${ }^{1}$, Pudji Astuti ${ }^{2}$ \\ \{enysulistyowati@unesa.ac.id ${ }^{1}$, pudjiastuti@unesa.ac.id ${ }^{2}$ \} \\ ${ }^{1,2}$ Universitas Negeri Surabaya, Indonesia
}

\begin{abstract}
In 2019, the Department of Culture and Tourism of Surabaya stated that there were 87 "restaurants", 776 restaurants and 14 food courts dumping waste every day. If waste is collected, the weight will reach $2.64 \%$ of the total volume of waste in Surabaya. Based on data from the Department of Sanitation of Surabaya shows the total volume of waste is $9,009.28 \mathrm{~m} 3$ in 2012 . The problem is that restaurant waste is not managed well. Urgency of the research is to identify waste management restaurants in Surabaya and constraints in order to obtain the right solution. Data is obtained through surveys, interviews and observations. The population is 87 managers of "restaurant" in Surabaya. Samples taken randomly. The sample is 20 restaurants. Data is analyzed qualitatively. The results showed that restaurant waste was put into special waste plastic without being sorted and disposed of in the trash. The janitor takes it. The challenge is that if refuse collector do not take out waste, then the waste will accumulate, the smell will disturb consumers, damage the scenery and spread disease. The research recommendation is to sort waste before being disposed. Waste is sorted between wet waste and dry waste. Wet rubbish is used as catfish or duck food. It is better for restaurant owners to work together with catfish and duck breeders regarding wet waste that has been sorted out.
\end{abstract}

Keywords: Restaurant Waste, Management, Challenges.

\section{Introduction}

Waste is still an unsolved problem especially for the city of Surabaya. Various types of waste contribute to the waste dumps in Surabaya, such as household waste, market waste, hospital waste, restaurant waste, restaurant waste and many other sources. The average volume of waste in the city of Surabaya is 319 grams per person per day, consisting of 250 grams of organic waste per person (75.58\%) and inorganic waste of 61 grams per person per day $(24.42 \%)[1]$.

According to the Japan International Cooperation Agency (JICA) Study Team as reported by the General Workers Department, between 1992-2010, waste in Surabaya grew 5\% annually. This is due to an increase in the population of around $1.6 \%$ per year, resulting in an increase in waste generation per capita of $3.4 \%$ per year.

The landfill management is still limited to collecting and stacking it in the landfill, processing it into compost and destroying it with an incinerator. There are still things that can be utilized in the case of rubbish, such as restaurant waste, food court trash, food stalls and restaurant waste. 
Restaurant waste can be used as a source of livestock food, such as food for duck or catfish. In this study the problems raised were related to the identification of types of waste, processing methods and barriers encountered by restaurants in processing their waste.

Identification is needed as a foothold in following up the method of processing restaurant waste. The restaurant was chosen as the object of research, arguing that the restaurant does not have good management in managing its business, including in processing the waste produced.

The purpose of this study is to identify the management and problems experienced by restaurant managers and to find solutions in overcoming waste problems in Surabaya, especially utilizing restaurant food scraps so that it has economic value. Its efficiency besides maintaining the environment can also maintain the health of the environment and the beauty of the scenery.

\section{Literature Review}

Environmental issues have always been a big issue in almost all urban areas related to waste problems [2]. Waste is the remnants of waste produced from a production process both industrial and domestic (household). Based on Law No. 18 of 2008 concerning Waste Management, it is stated that waste is the residual daily activities of humans or natural processes in the form of solid or semi-solid in the form of decomposed or inorganic substances which are considered to be useless and disposed of environment. Waste can come from households, factories, hospitals, markets or restaurants, and so on.

Waste from its origin are organic waste and inorganic waste. Organic waste is produced from biological materials that can be degraded by microbes or biodegradable. This waste can easily be decomposed through natural processes. Inorganic waste is produced from nonbiological ingredients. Most inorganic waste cannot be decomposed by nature/microorganisms overall (unbiodegradable). The rest can only be decomposed in a long time.

The composition of waste in Indonesia is dominated by organic waste from food waste, while this type of waste management has received special attention in several countries such as the United States, Singapore, and the United Kingdom, in Indonesia organic waste management is still focused on methods landfilling [3]. The results of Nilam Sari's research show that most of the waste is still dumped carelessly which potentially damage the environment. Environmental pollution causes an increase in the spread of disease, reduces environmental aesthetics, and impacts on global warming. The results of the study indicate that there is no specific planning in waste management due to the absence of a waste management place [4]. The technical problems faced in managing left over food waste are a lack of government awareness in providing food waste processing facilities specifically and a lack of public awareness to do waste sorting [5] .

The Increasing the amount of waste that is not balanced by environmentally friendly management will cause environmental destruction and pollution [6]. Waste that has been thrown away, evidently can still be reused as source of fodder.

Therefore, the management of waste in order not to pollute the environment and disturb health, it is necessary to have legal certainty on regulation of the waste management. Based on this reason, Law No. 18 of 2018 concerning Waste Management was issued.

Article 5 of Law No. 18 of 2018 regulates the duties of the government and regional governments to ensure the implementation of good and environmentally sound waste management. The tasks of the Government and Regional Government include:

a. Developing and increasing public awareness in waste management 
b. Conducting research, developing reduction technology, and handling waste

c. Facilitating, developing and implementing efforts to reduce, handle and utilize waste

d. Carry out waste management and facilitate the provision of infrastructure and facilities waste management

e. Encourage and facilitate the development of benefits from the results of waste management

f. Facilitate the application of specific local technologies that develop in local communities to reduce and handle waste

g. Coordinate between government agencies, communities and the business world so that there is integration in waste management.

Local governments are authorized to make policies in realizing waste management tasks. While the implementation is needed community participation.

The Government of Surabaya issued the Regional Regulations No. 5 of 2014 concerning waste management and the cleanliness of Surabaya. But the regulation has not been able to solve the existing waste problems. On this occasion the researcher will identify methods for processing restaurant waste and the challenge as a foundation for finding solutions to waste processing in Surabaya.

\section{Methodology}

The implementation of this restaurant waste management study uses a descriptive method that aims to obtain factual and accurate facts about the types of waste, processing methods and obstacles encountered by restaurant entrepreneurs in Surabaya.

The search for the data needed will be done using the survey method. The researcher will conduct interviews and observations to obtain facts from the existing symptoms and look for information in fact related to restaurant waste.

The management of restaurants in Surabaya as the population. Based on data obtained from the Department of Culture and Tourism of Surabaya, in 2019 there were 87 restaurants in Surabaya. The sample was taken randomly totaling 18 restaurants (20\% of the population). The data obtained will be analyzed qualitatively.

\section{Result}

The results of the observation showed that the types of restaurant waste in Surabaya were organic and inorganic. Organic waste is in the form of unused waste of vegetables and fruits as well as food scraps that are served and not spent by customers. While organic waste in the form of paper, cans, and plastic packaging of food ingredients will be processed. In addition there are also glasses and bottles of used drinks and processed materials such as bottles of soy sauce, tomato sauce and others.

Processing of both organic and an-organic waste is just put into special plastic bags for waste without being sorted, then dumped in the trash that will be taken by the refuse collector.

The results of interviews that waste management by including in special waste plastic was carried out to make it easier for waste workers to transport the waste. The challenges include the absence of staff assigned to sort out waste, because it will increase the cost. In addition, if 
the refuse collector does not pick up waste, then the waste will accumulate which causes odor, eyesores, thus reducing the amount of customer.

The results showed that restaurant waste is still a problem for Surabaya, because it is not managed properly. Restaurant management believe has been obey the Regional Regulation No. 5 of 2014 concerning waste management and cleanliness of Surabaya, which relies on landfill only. The Regional Regulation No. 5 of 2014 has not been implemented properly, due to lack of supervision from local governments.

Restaurant waste that has been piled up and has not been taken yet by refuse collector is the source of diseases, as stated by Noto Atmodjo in his research entitled "Public Health: Science and Art". Basically, most of the rest of the restaurant can still be managed as a source of fodder.

Managing restaurant waste does need special attention from the local government and public awareness. The community needs to be aware that waste can be processed and utilized. While the government needs to supervise and provides learning for the community on waste management. Hopefully waste not be a problem anymore in the future

\section{Conclusions}

The conclusion of this study is that waste management in restaurants has not been managed properly because waste is only collected and disposed without sorting and still depends on the refuse collector. The challenges faced by managers of restaurants in managing waste include the absence of waste sorting workers and their dependence on refuse collector.

The recommendation proposed is to provide organic and inorganic bins, so that when disposing of waste there is no need to separate them manually. Organic waste is disposed in organic waste bin and inorganic waste is disposed in inorganic waste bin. For organic waste, it should be used as food for catfish or ducks. Therefore, it is recommended that restaurant managers work together with catfish or duck farmers in managing their waste.

\subsection{Acknowledgements}

We would like to thank the Dean of the Faculty of Social Sciences and Law at the Universitas Negeri Surabaya for the opportunity given to us to carry out this research

\section{References}

[1] https://tirto.id/mewujudkan-mimpi-restoran-bebas-sampah-bJEf. "Realizing the Dream of a Waste-Free Restaurant

[2] https://www.kompasiana.com/alifianahr/550d33de8133111622b1e24f/manelola samphdi-perkurban-studi-kasus-masalah-sampah-di-surabaya

[3] Febrianie." Problematic Waste Management "in Kompas January 102004.

[4] Journal of Environmental Engineering, Bandung Institute of Technology Vol 19 No. 1 of 2013. Brigadier. "Analysis of Food Waste Management in the City of Bandung."

[5] Andalas Public Health Journal (Andalas Journal of Public Health). Vol 10, No. 2 (2016). Patchouli Sari, et al. Analysis of Solid Waste Management in Banuhampu Subdistrict, Agam District. 
[6] Notoatmodjo, Soekidjo. 2011. Public Health: Science and Art. Jakarta: Rineka Cipta. P. 5.

[7] Law No. 18 Year 2018 concerningWaste Management

[8] PERDA No. 5 In 2014 regarding waste management and cleanliness of the city of Surabaya 